\title{
EXPLORATION OF THE FUTURE - A KEY TO SUSTAINABLE DEVELOPMENT
}

Vatroslav Zovko*

Faculty of Teacher Education - University of Zagreb

Zagreb, Croatia

DOI: 10.7906/indecs.11.1.8

Received: 26 December 2012.

Regular article

Accepted: 25 January 2013.

\section{ABSTRACT}

Throughout the history people were fascinated and curious about the future. The future was, and still is seen as a key for prosperous development in all aspects of the society. As such, new discipline is developed - future studies.

This paper discusses the discipline of future studies and its role in the society and science. Future studies are analyzed in the context of sustainable development. It is argued that future studies and sustainable development are complementary in nature. Based on analysis of most developed countries in the world, that spend the greatest portion of their budget on research, development and science in comparison to the rest of the world, there is a conclusive link between investments in research, development and science, and the recognition of the importance of thinking about the future. Those countries started to formalize their future orientation in many respected research centres and universities through their educational programs and research. That situation poses the need for other, less well off countries, to follow up.

\section{KEY WORDS}

future studies, strategic foresight, sustainable development, economic growth, universities

\section{CLASSIFICATION}

JEL: $\quad$ O39, Q01 


\section{INTRODUCTION}

Rapid production of new knowledge and, consequently, high innovation rate that results in new technologies fundamentally changes the way we live. The impression is that most societies are surprised by these changes. In other words, we were not prepared for yesterday's future that caught us today. Countries that are more conscious about the future better cope with change and make easier transition to the new circumstances in the global socio economic environment which results, among other things in their superior economic position.

\section{FUTURE STUDIES}

People were always interested in the future and accordingly they tried to plan their activities in all aspects of life and society. There are myriad examples of prediction efforts thorough the history; from ancient Egypt to present times. Through prediction, people tried to diminish uncertainty and to prepare themselves for the coming times. Although the main concern of the art of prediction is the future, it cannot be used as a synonym for future studies. Prediction comes from the word to predict which is defined as an act "to declare or indicate in advance ... foretell on a basis of observation, experience, or scientific reason" [1]. Therefore, the word prediction refers to "a statement that says what you think will happen; the act of making such a statement" [2]. Therefore, prediction is concerned with upcoming events not necessarily explaining the context or other consequences that would lead to other upcoming events. Prediction is focused, often missing holistic view. In other words, prediction is concerned with future facts not the meaning or the context because it is "path dependent: it matters how we got there" [3; p.13]. In other words, prediction relies primarily on our past experiences (history). Things that are not seen as path dependent are often regarded as illusionary, as science fiction, as a figment of imagination, not based on reality and our previous experiences. So, that is the point where future studies come in.

Future studies can generally be defined as "an empirical and scientifically based approach to understanding the future" [4; p.109]. They are concerned with investigation of possible futures - what can actually happen, probable futures - which are most likely to happen, and preferable futures - what should happen [5]. Future studies are often taken as a synonym for technology assessment, as analysis of past, present and future technologies represent standard approach to future research [6; p.8]. Most of people under the term technology consider only an object or a tool for a specific purpose and that clearly is not the subject of the future studies research. One of the main concerns of future studies is technology but not as "a system of machines with certain functions; but rather as an expression of a social world" [7; p.47]. Basically, main aim of the futurologists is to improve human well being and the whole world, often making future world scenarios self fulfilling prophecies.

First futurologists were science fiction writers. The beginning of futurology many authors trace back to 1901 when H.G. Wells published his book Anticipations of the Reactions of Mechanical and Scientific Progress upon Human Life and Thought [8; p.185, 9; p.552], in which he made predictions for the next 100 years where some of them proved to be accurate $[10,11]$. There are many other notable fiction and nonfiction writers that largely contributed to development of future studies in the last century, such as: Arthur C. Clarke with his book Profiles of the Future: An Inquiry into the Limits of the Possible where he made predictions about the future with a firm grounding in the laws of science, of which some already became true (i.e. global TV and radio \& cellular phones) [12], Alvin Tofler with his work The Future Shock where he predicts environmental change and points out major challenges which will individuals and societies face in the future [13], Carl Sagan with his work The Dragons of 
Eden: Speculations on the Evolution of Human Intelligence where he speculates about artificial and extraterrestrial intelligence based on human evolution [14] and Ray Kurzwiel with his book The Age of Spiritual Machines: When Computers Exceed human Intelligence where he foresees that artificial intelligence will surpass human intelligence by the year 2020 and anticipates amalgamation of human and artificial intelligence [15]. Apart from nonfictional work mentioned above, it is also important to mention Isaac Asimov's novel Foundation written in 1951, where he envisioned the rise of psychohistory which he has defined "...to be that branch of mathematics which deals with the reactions of human conglomerates to fixed social and economic stimuli..." $[16 ;$ p.16], or in other words, psychohistory deals with development of future scenarios of actions of large human groups (populations) which can be referred to as one of the first definitions of future studies.

First institution that systematically approached future issues (mainly related to military) is RAND Corporation that was established in 1945 [17]. Today, they are intensively working on exploration of future beyond military issues in their Frederick S. Pardee Center for Longer Range Global Policy and the Future Human Condition [18]. In 1966, in Washington DC, a group of individuals founded a World Future Society [19], that is publishing bimonthly journal The Futurist and peer-reviewed journal World Future Review. In 1974, University of Houston initiated first masters program in Future studies in the world that is still operational today [20]. Today, there are a total of 22 future studies (or strategic foresight) programs as a major programs of study in different countries [21] promising to establish future studies as widely accepted and recognized scientific discipline.

\section{SUSTAINABLE DEVELOPMENT}

Sustainable development represents an answer to the problems posed by traditional development that is focused exclusively on economic growth while the changes in other parts of society are just a consequence. Today, the term sustainable development is closely linked with the term sustainability that refers primarily to ecological issues (relationship between biological organisms and their environment) while in its roots, as Baker argues, "the chief focus of sustainable development is on society". She further explains that sustainable development is refers to coordination of societal change between social, economic and ecological aspects of society that represent three pillars of sustainable development [22; p.7]. The whole concept of sustainable development is future oriented as the United Nations definition of the concept states: "Sustainable development is development that meets the needs of the present without compromising the ability of future generations to meet their own needs" [23]. Or, as Baker states, sustainable development is about visioning alternative futures and embracing one that is sustainable [22; p.8]. In other words, sustainable development deals with development of different sets of future scenarios and putting all the efforts to realize the most preferable one. To make sustainable development concept (or a style of life) widely accepted people need a common understanding of the future, the good and the bad version of it. The path to understanding is through visualisation of abstract concepts and their communication not just to scientific community, but to the entire society.

\section{OVERVIEW OF MOST DEVELOPED COUNTRIES IN THE WORLD}

Most developed countries in the world are predominately knowledge oriented with largely diversified economies, where high percentage of their gross domestic product (GDP) goes to research and development activities in both private and public sectors. According to World Bank data [24] (Table 1) country with the highest gross national income (GNI) per capita ${ }^{1}$ is Qatar whose success is contributed mainly by their natural (oil and gas) reserves which account for more than $85 \%$ of their exports, and for more than $50 \%$ of GDP [24]. That data 
Table 1. Top 25 countries per GNI per capita in 2011.

\begin{tabular}{|c|l|c|}
\hline Rank Country & GNI per capita, \$ \\
\hline 1. & Qatar & 86440,00 \\
\hline 2. & Luxembourg & 64260,00 \\
\hline 3. & Norway & 61460,00 \\
\hline 4. & Singapore & 59380,00 \\
\hline 5. & Switzerland & 52570,00 \\
\hline 6. & Hong Kong SAR, China & 52350,00 \\
\hline 7. & United States & 48820,00 \\
\hline 8. & United Arab Emirates & 47890,00 \\
\hline 9. & Netherlands & 43140,00 \\
\hline 10. & Sweden & 42200,00 \\
\hline 11. & Austria & 42050,00 \\
\hline 12. & Denmark & 41900,00 \\
\hline 13. & Germany & 40230,00 \\
\hline 14. & Canada & 39660,00 \\
\hline 15. & Belgium & 39190,00 \\
\hline 16. & Australia & 38110,00 \\
\hline 17. & Finland & 37670,00 \\
\hline 18. & United Kingdom & 36010,00 \\
\hline 19. & France & 35910,00 \\
\hline 20. & Japan & 35330,00 \\
\hline 21. & Ireland & 34180,00 \\
\hline 22. & Italy & 310200,00 \\
\hline 23. & Spain & 370,00 \\
\hline 24. & Iceland & \\
\hline 25. & Korea, Rep. & \\
\hline & & 3100 \\
\hline
\end{tabular}

is consistent with their research and development $(R \& D)$ potential as petroleum refining is considered medium-low technology sector [25]; if we use as an indicator of R\&D potential the number of published scientific journal articles, according to World Bank data [26], in year 2009 Qatar published only 64 articles what in comparison to top ranked United States with total of 208601 articles, is fairly low. Similar is the case of Luxembourg with 137 published articles and United Arab Emirates with 265 published articles respectively. Singapore, as a fairly small country, in year 2009 published 4187 articles what ranks him on high 28th place.

The World Bank data on expenditure for R\&D as a percentage of Gross Domestic Product (GDP) slightly changes the picture [27] (14 years average). Neither Qatar nor the United Arab Emirates are among top 25 countries in spending on R\&D. As related to other countries, top 25 list is similar to that of GNI per capita (Table 2). Only serious newcomer to the top 25 list is Israel that on average spends more than $4 \%$ of its GDP on R\&D (which is consistent with their production of 6304 scientific articles in year 2009).

To elaborate things further, we should look at the Academic Ranking of World Universities (ARWU), or popularly called the Shanghai List that is updated annually since year 2003. Universities are ranked by following indicators: "number of alumni and staff winning Nobel Prizes and Fields Medals, number of highly cited researchers selected by Thomson Scientific, number of articles published in journals of Nature and Science, number of articles indexed in Science Citation Index - Expanded and Social Sciences Citation Index, and per capita 
Table 2. 14 years average spending on research and development as a percentage of GDP.

\begin{tabular}{|c|c|c|}
\hline Rank & Country & $\begin{array}{c}14 \text { year average R\&D spending, } \\
\% \text { of GDP }\end{array}$ \\
\hline 1. & Israel & 4,08 \\
\hline 2. & Sweden & 3,65 \\
\hline 3. & Finland & 3,31 \\
\hline 4. & Japan & 3,15 \\
\hline 5 . & Switzerland & 2,77 \\
\hline 6. & Korea, Rep. & 2,63 \\
\hline 7. & United States & 2,63 \\
\hline 8. & Iceland & 2,60 \\
\hline 9. & Germany & 2,47 \\
\hline 10. & Denmark & 2,41 \\
\hline 11. & Austria & 2,18 \\
\hline 12. & France & 2,17 \\
\hline 13. & Singapore & 2,00 \\
\hline 14. & Canada & 1,91 \\
\hline 15. & Belgium & 1,90 \\
\hline 16. & Netherlands & 1,87 \\
\hline 17. & Australia & 1,83 \\
\hline 18. & United Kingdom & 1,78 \\
\hline 19. & Norway & 1,63 \\
\hline 20. & Luxembourg & 1,62 \\
\hline 21. & Slovenia & 1,45 \\
\hline 22. & Czech Republic & 1,28 \\
\hline 23. & Ireland & 1,27 \\
\hline 24. & New Zealand & 1,11 \\
\hline 25. & Italy & 1,10 \\
\hline
\end{tabular}

performance with respect to the size of an institution“" [28]. List includes top 500 universities around the globe. For the year 2012 first 100 positions are held by universities from 16 countries [29]. The dominant country is United States with total of 53 universities, followed by United Kingdom with 9 universities (Table 3).

Other important thing to mention is that all countries that are represented in the first 100 positions, apart from Russia, are also present in the list of top 25 countries by GNI per capita and 14 years average spending on R\&D as a percentage of GDP.

\section{CONSCIOUSNESS ABOUT THE FUTURE - COMMON DENOMINATOR OF MOST DEVELOPED COUNTRIES}

Previous section gives an overview of most developed countries together with R\&D potential. Vision of the future that is usually formally presented as a strategic plan (or strategy paper) represents major guiding point for $\mathrm{R} \& \mathrm{D}$ efforts. That is recognized in all advanced economies. In example, UK Department for Business, Innovation \& Skills states that "... if we are to realise our vision for the UK's future we need to strengthen our innovative capability and encourage investment in innovation" [30]. The importance of exploration of the future and future orientation for national economies and sustainable development is slowly becoming recognized by universities throughout the world, especially among most 
Table 3. Ranking of countries by the number of universities in the first 100 positions on the ARWU for the year 2012.

\begin{tabular}{|r|l|c|}
\hline Rank Country & Number of universities \\
\hline 1. & United States & 53 \\
\hline 2. & United Kingdom & 9 \\
\hline 3. & Australia & 5 \\
\hline 4. & Canada & 4 \\
\hline 5. & Switzerland & 4 \\
\hline 6. & Germany & 4 \\
\hline 7. & Japan & 4 \\
\hline 8. & France & 3 \\
\hline 9. & Israel & 3 \\
\hline 10. & Sweden & 3 \\
\hline 11. & Denmark & 2 \\
\hline 12. & Netherlands & 2 \\
\hline 13. & Belgium & 1 \\
\hline 14. & Finland & 1 \\
\hline 15. & Norway & 1 \\
\hline 16. & Russia & 1 \\
\hline
\end{tabular}

developed countries. Acceleration Studies Foundation, a non profit organization dedicated to promotion of education about the future, comprised a list of graduate programs that offer degrees and courses in future studies (or, as they state, foresight programs) [20]. The list is divided in three parts: list of universities (and programs) that offer primary Master of Science and Doctorate degrees in future studies - a total of 22 universities; list of universities with secondary future studies programs that put a notable emphasis on any of the primary foresight subjects or have on-campus futures research centres which may be used for potential affiliations during graduate study - a total of 83 universities and a list of universities with program potentials but that do not offer a degree study or an option of potential affiliation during graduate study - a total of 13 universities. When analyzed in the context of top 25 GNI per capita ranking, top 25 R\&D spending as a percentage of GDP ranking and the top 100 ranking on the ARWU, all countries apart from Norway and Switzerland have some form of university level education in future studies (Table 4) or future studies research centres.

The surprising fact is that only 18 , out of top 100 universities in the world offer some kind of education in future studies. But, nevertheless, it is evident that academic community is becoming aware of the importance of future studies; first four universities on the ARWU offer future studies as secondary programs:

- Harvard University has founded Berkman Center for Internet \& Society that is dedicated to exploration of cyber space and as such is involved into doctorate degree program in law,

- Stanford University offers MBA study and doctorate degree program that is oriented toward future studies and is supported by the Foresight and Innovation program, by The Center for Internet and Society, and by the Center for Social Innovation,

- Massachusetts Institute of Technology offers a graduate, doctorate program in Science, technology and society at the School of Humanities, Arts, and Social Sciences,

- University of California Berkley offers graduate degree programs at three schools: at the Institute of Transportation Studies, at the Haas School of Business and at the School of Information. 
Table 4. Number of universities per country offering some kind of education in future studies.

\begin{tabular}{|l|c|c|c|}
\hline \multicolumn{1}{|c|}{ Country } & $\begin{array}{c}\text { No. of universities } \\
\text { with primary } \\
\text { program }\end{array}$ & $\begin{array}{c}\text { No. of universities } \\
\text { with secondary } \\
\text { program }\end{array}$ & $\begin{array}{c}\text { No. of universities } \\
\text { with potential } \\
\text { programs }\end{array}$ \\
\hline United States & 4 & 39 & 4 \\
\hline $\begin{array}{l}\text { United } \\
\text { Kingdom }\end{array}$ & 0 & 12 & 2 \\
\hline Australia & 1 & 3 & 0 \\
\hline Canada & 1 & 3 & 0 \\
\hline Switzerland & 0 & 0 & 0 \\
\hline Germany & 2 & 1 & 0 \\
\hline Japan & 0 & 1 & 1 \\
\hline France & 1 & 3 & 1 \\
\hline Israel & 0 & 2 & 0 \\
\hline Sweden & 0 & 2 & 0 \\
\hline Denmark & 1 & 0 & 0 \\
\hline Netherlands & 0 & 2 & 0 \\
\hline Belgium & 0 & 1 & 0 \\
\hline Finland & 1 & 0 & 0 \\
\hline Norway & 0 & 0 & 1 \\
\hline Russia & 0 & 1 & \\
\hline
\end{tabular}

\section{CONCLUSIONS}

Sustainable development is clearly defined by our perception of the future. To have clear perception of the future, societies need to develop think tanks of future oriented experts that would support R\&D efforts towards prosperous future. In that manner, future thinking cannot be reserved only for technology experts. The approach to future thinking is interdisciplinary in its nature. It should include experts from all areas of human work. As such, these experts should work on viable future scenarios that would lead to consensus about what kind of future we want. Although most developed countries are already in early stages of future studies development, sustainable development needs inclusion of all countries because social, economic and ecological problems in today's world represent global issues that need global consensus on common future.

Only the most powerful economies invest in future studies research, therefore this scientific discipline represents an upgrade in research efforts aimed at driving society towards sustainable development based on all three pillars. As above mentioned countries that are leaders in future studies have not only economic, but also human potential means for conducting research of all aspects of the future, it is expected that exactly these countries will become leaders in future development of a true global society. Academic community is becoming aware of the importance of future studies, and therefore, apart from above mentioned countries; it is important that other countries are included in the development of this scientific discipline so that the future scenarios include local differences and preferences aimed at the ultimate goal of fulfilment of global progress and sustainability. 


\section{REMARK}

${ }^{1} \mathrm{GNI}$ is preferred indicator of countries performance because GDP can be misleading. For detailed explanation refer to article GDP and GNI, OECD Observer, No. 246-247, December 2004-January 2005, http://bit.ly/WrxZQO, accessed 26 December 2012.

\section{REFERENCES}

[1] -: Predict.

Merriam-Webster Dictionary, Merriam-Webster Incorporated, 2012, http://www.merriam-webster.com/dictionary/predict, accessed 26 December 2012,

[2] -: Prediction.

Oxford Advanced Learners Dictionary, Oxford University Press, 2011, http://oald8.oxfordlearnersdictionaries.com/dictionary/prediction, accessed 26 December 2012,

[3] Orrell, D.: The Future of Everything - The Science of Prediction. Thunder's Mouth Press, New York, 2007,

[4] Lombardo T.: Contemporary Futurist Thought. Author House, Bloomington, Milton Keynes, 2008,

[5] Bell, W. according to Hicks D.: Teaching for a Better World: A Futures Perspective. http://teaching4abetterworld.co.uk/futures.html, accessed 26 December 2012,

[6] Bell, W.: Foundations of future Studies: History, Purposes, and Knowledge. Transaction Publishers, Piscataway, 2003,

[7] Nye, D.E.: Technology Matters: Questions to Live With. The MIT Press, Cambridge, London, 2006,

[8] Page, M.R.: The Literary Imagination from Erasmus Darwin to H.G. Wells: Science, Evolution and Ecology.

Ashgate Publishing, Farnham, Burlington, 2012,

[9] Kuper, A. and Kuper, J.: The Social science Encyclopedia. $2^{\text {nd }}$ ed.

Routledge, New York, 2003,

[10] Crabtree, P.: Anticipations: The Remarkable Forecasts of H.G. Wells.

The Futurist 41(5), pp. 40-47, 2007,

[11] Zenko, M.: Predicting Future War: What H.G. Wells Got Right and Wrong. Council on foreign Relations, 27.12. 2011, http://blogs.cfr.org/zenko/2011/12/27/predictingfuture-war-what-h-g-wells-got-right-and-wrong, accessed 26 December 2012,

[12] Clarke, A.C.: Profiles of the Future: An Inquiry into the Limits of the Possible. Indigo paperback, London, 2000,

[13] Tofler, A.: Future Shock. In Croatian. Otokar Keršovani, Rijeka, 1975,

[14] Sagan, C.: The Dragons of Eden Speculations on the Evolution of Human Intelligence. Ballantine books, New York, 1978,

[15] Kurzweil, R.: The Age of Spiritual Machines: When Computers Exceed human Intelligence. Penguin Books, London, Toronto, Ringwood, Auckland, 2000,

[16] Asimov, I.: Foundation. Bantam Dell, New York, 1991,

[17] RAND corporation: History and Mission. http://www.rand.org/about/history.html, accessed 26 December 2012,

[18] Rand Corporation: Pardee Center. http://www.rand.org/international_programs/pardee.html, accessed 26 December 2012,

[19] Cornish, E.: The World Future Society's First Conference. The Futurist 41(3), 43-48, 2007,

[20] University of Houston: Future Studies Degree at UH Kicks Off in Fall 2008. University of Houston, 2012, http://bit.ly/jKR4Hh, accessed 26 December 2012, 
[21] Acceleration Studies Foundation: Foresight Graduate Programs - Global List. http://accelerating.org/gradprograms.html, accessed 26 December 2012,

[22] Baker, S.: Sustainable Development. Routledge, New York, 2006,

[23] World Commission on Environment and Development: Gathering a body of global agreements: Our Common Future.

Report, World Commission on Environment and Development, Ch. 2, http://www.un-documents.net/ocf-02.htm, accessed 26 December 2012,

[24] -: GNI per capita, Atlas Metod, (Current US\$).

The World Bank Group, 2012, http://data.worldbank.org/indicator/NY.GNP.PCAP.CD/countries, accessed 26 December 2012,

[25] -: The World Factbook - Qatar.

Central Intelligence Agency, 2012, https:/www.cia.gov/library/publications/the-world-factbook/geos/qa.html, accessed 26 December 2012,

[26] Hatzichronoglou, T.: Revision of the High-Technology Sector and Product Classification. OECD Science, Technology and Industry Working Papers 1997/02, 1997, http://dx.doi.org/10.1787/134337307632,

[27] -: Scientific and Technical Journal Articles.

The World Bank Group, 2012,

http://data.worldbank.org/indicator/IP.JRN.ARTC.SC/countries, accessed 26 December 2012,

[28] -: Research and development expenditure (as a \% of GDP).

The World Bank Group, 2012,

http://data.worldbank.org/indicator/GB.XPD.RSDV.GD.ZS/countries, accessed 26 December 2012,

[29] Academic Ranking of World Universities: About Academic Ranking of World Universities.

Shanghai Ranking Consultancy, 2012.

http://www.shanghairanking.com/aboutarwu.html, accessed 26 December 2012,

[30] Academic Ranking of World Universities: Academic Ranking of World Universities - 2012.

Shanghai Ranking Consultancy, 2012,

http://www.shanghairanking.com/ARWU2012.html, accessed 26 December 2012,

[31] -: Innovation and Research Strategy for Growth.

Department for Business Innovation \& Skills,2012,

http://www.bis.gov.uk/innovatingforgrowth, accessed 26 December 2012.

\section{ISTRAŽIVANJE BUDUĆNOSTI - KLJUČ ODRŽIVOG RAZVOJA}

V. Zovko

Učiteljski Fakultet - Sveučilište u Zagrebu

Zagreb, Hrvatska

\section{SAŽETAK}

Tijekom povijesti ljudi su iskazivali svoju znatiželju i interes za budućnost. Orijentacija budućnosti se oduvijek smatrala ključem prosperitetnog razvoja svih segmenata suvremenog društva. U tom kontekstu se i razvija nova disciplina - futurologija.

Članak u uvodnom dijelu daje osvrt na futurologiju i njenu ulogu u društvu i znanosti. Futurologija je predstavljena iz perspektive održivog razvoja čime se argumentira kako su futurologija i održivi razvoj komplementarne discipline. Temeljem analize najrazvijenijih država svijeta koje imaju i najvišu stopu izdvajanja iz bruto društvenog proizvoda za istraživanje i razvoj uspostavlja se korelacija između investicija u istraživanje, razvoj $\mathrm{i}$ znanost te percepcije važnosti promišljanja o budućnosti na nacionalnoj razini. Najrazvijenije države svijeta počeli su i službeno uvažavati futurologiju kroz osnivanje istraživačkih centara te 
pokretanjem niza sveučilišnih programa koji u svojim temeljima sadrže futurologiju. Ovakva situacija nameće potrebu da se i manje razvijene države priključe trendu istraživanja budućnosti.

\section{KLJUČNE RIJEČı}

futurologija, strateško predviđanje, održivi razvoj, ekonomski rast, sveučilišta 